\title{
WHAT MAKES UNIVERSITY STUDENTS SWEAR
}

\author{
Svitlana Babushko \\ National University of Ukraine on Physical Education and Sport, Kyiv, Ukraine \\ babushko64sr@gmail.com
}

Liudmyla Solovei

Borys Grinchenko Kyiv University, Kyiv, Ukraine

1.solovei@kubg.edu.ua

\begin{abstract}
The problem of swearing by youth in public is becoming acute nowadays. A growing tendency can be traced in Ukraine that young women are on equal terms with men in this respect. The authors of the article explored the reasons of using non-standard language by Ukrainian students under modern conditions and specified what should be done to improve their speech culture and eliminate their swearing. The primary aim of the research is to find out the motives why Ukrainian university students swear in their everyday life. To achieve the goal a special questionnaire was designed. All in all, 118 respondents of 2 age groups participated in the survey. Differences and similarities in using swear words by junior and senior students were investigated according to 3 criteria: motives, types of emotions, recommendations of eliminating or at least minimising this phenomenon. As it is shown by results of the research, the most typical motive of using non-standard language for males and females is the opportunity to express both negative and positive emotions. Neither juniors nor seniors considered it to be extraordinary. Yet, they agreed that various educational activities should be arranged to eliminate the usage of swear words and uplevel the speech culture of university students.
\end{abstract}

Keywords: swear words; university students; Ukraine; motives; emotions; recommendations.

\section{Introduction}

Language is considered the most valuable treasure of every nation. It reflects the culture of the people. The fact that members of the society are using non-standard lexis means something is going wrong in this community. Although swearing has been used by people since ancient times (Ljung, 2011), or even since the emergence of language (Vingerhoets, Bylsma \& de Vlam, 2013), the problem of its use in social interaction still remains. It is actualised to a greater degree in modern times because, as Pinker (2007) states, swearing is becoming more acceptable with each new generation.

Young people are observed to be using swear words in public without any humbleness and shyness. It has become a growing trend in the Ukrainian society. Another noticeable tendency is that Ukrainians prefer to use swear words in Russian, even those whose mother tongue is Ukrainian. The mentioned tendency, as it is, may be explained with several reasons. Firstly, a historical reason: 80 per cent of Ukrainian ethnic territory and 85 percent of the Ukrainian population were under Russian empire reign since the $18^{\text {th }}$ century (Grycak, 2019). Its total control was aimed at destroying the national identity of Ukrainians and it lasted until Ukraine became independent in 1991. Due to the dominant position of the Russian language on the Ukrainian territory, people are accustomed to using Russian swearing words. The similar phenomenon is seen when Asian and Arab students swear not in their native language but using English (Finn, 2017, p. 22). Secondly, because of stricter social constraints and higher speech culture which were originally typical to Ukrainians. Thus, for the majority of young people addressing to non-standard words in Russian seems a good way to avoid breaking social and literary norms of the Ukrainian language.

The use of non-standard language (obscene, profanity, taboo words, etc) has been under consideration of scholars in different scientific fields: philology, pedagogy, psychology, philosophy, sociology. From a linguistic point of view, the foreign and Ukrainian researchers investigate forms, usage and real examples of swearing in different languages (Jay \& Jay, 2015; Kleputs, 2009). Thus, McEnery (2006) distinguishes and characterises the following types of swearing: swear words, animal, sexist, intellect-based, racist and homophobic terms of abuse. Comparative linguistic study of the problem is represented in Kleputs (2009). Ljung (2011) investigates cross-cultural linguistic aspect, analyses shape, use and manifestations of swear words in mother tongue and compares the corresponding lexical units, their meaning, grammar constructions in a number of other languages.

From socio-linguistic perspective, the use of swearing is seen as a type of linguistic behaviour. Particularly, Fägersten (2012) presents the problem of swear word usage in a new light focusing on its pragmatic functions, underlining the relationship between swearing and impetus, offensiveness and context from a sociolinguistic perspective. Formanova (2013), a Ukrainian scholar, studies swear words, their types 
in the Ukrainian language and their explication in gender and social aspects. Lavryk (2010) analyses moral aspects of using non-standard lexicon in modern Ukrainian social media. The researcher mentions the administrative penalties for the use of any swearing in public, the introduction of the language censorship for the mass media, the increase of their social responsibility, and the open discussion of the problem.

Swearing is seen as a psychological and health problem by foreign scientists (Rassin \& Murris, 2005; Mehl \& Pennebaker, 2003; Pinker, 2007; Vingerhoets, Bylsma \& de Vlam, 2013). The aspect is also in the field of the Ukrainian researchers' interest. Investigating the reasons of using non-standard language from socio- and psycholinguistic aspect, L. Rostomova (2012) states that the increase of swearing is caused by the emotional intensification of everyday communication. In turn, it results in the change of speech standards. One more reason is that mass media became the standard language determinant. Empirical data which are received by Rostomova testify that $25 \%$ of students constantly use swearing in their everyday speech, $70 \%$ do it from time to time, whereas the percentage of those who never use it is only 5\%. Recent investigation by Shevchenko and Talko (2017) represents the results of the psychological and cultural analysis of swear word usage by young people and identifies the reasons why swearing is popular with them. In addition, the researchers demonstrate the definite cross-cultural differences in using swearing by Germans, Japanese, Arabic people and others.

Pedagogical studies are aimed at identifying effective tools of managing swearing in classrooms, preventing young and adult people from using swear words or at least minimising them (Finn, 2017; Hansen, 2016; Guvendir, 2015). It should be noted that there are 2 quite opposite points of view for swear word usage: the one that justifies and approves their use (Byrne, 2017; Baruch, Prouska et al, 2017). Byrne (2017) reveals that "swearing is likely to have been one of the first forms of language that we developed, and it's been helping us to deal with pain, work together, manage our emotions and improve our minds". The opponents are sure that swearing is "a powerful weapon of mass destruction" (Bagdasarov \& Tkachiov, 2012). Hence, there are more questions than answers and this study considers the problem from the pedagogical angle.

A wide thematic range of the researches devoted to the swear lexis is reflected in the variety of concepts denoting it. The literature overview shows that the most common words for non-standard lexis are: swear words, obscene, four-letter, profanity, taboo, strong, bad, vulgar words, to name a few. There is one feature that unites them. These words always trigger intense emotions and reactions, both positive and negative (Finn, 2017, p.18). The term "swearing" is used in this research.

Traditionally, it is believed that the use of swear lexis is typical to lower socio-economic welfare people because they do not run the risk of damaging their social status (Hansen, 2016). Obviously, university students can easily ruin their position, especially when doing it in public. According to the Ukrainian legislation, it is considered to be an administrative offence, particularly hooliganism. The penalty varies but is very strict: to pay a fine from 3 to 7 minimal income of the citizens; or public service from 40 to 60 hours; or corrective labour from 1 to 2 months with $20 \%$ distraction from the salary; or even the imprisonment for 15 days (Code of Ukraine on Administrative Offences, Article 173).

This research aims to find out the reasons of using swear words by Ukrainian students under modern conditions and specify what should be done to eliminate their usage and to uplevel their speech culture.

To achieve the goal, the following tasks should be performed:

- to examine the frequency of using swear words by students and learn if the gender, age and place of origin influence it;

- to investigate the motives of their application;

- to analyse the students' recommendations of what is necessary to be done to uplevel the speech culture of Ukrainian students.

\section{Methods}

It is possible to draw on different methodologies in designing research and analysing data (Cohen, Manion, \& Morrison, 2000, p.6). However, to validate the results of any pedagogic research the most frequently used methods are qualitative and quantitative. Their combination gives the most objective results of the research due to the fact that both have some advantages and disadvantages. In their unity, they balance the limitations of each other and can produce a richer and more comprehensive understanding of the research area.

Traditionally, quantitative research methods are aimed at collecting numerical data to explain the investigated phenomena and then analysing the information using mathematical based methods, in particular, statistics (Aliaga \& Gunderson, 2005). In this paper, the data was collected with the help of the specially designed questionnaire, some of which provided the data to be used in graphs and tables, i.e. the information that can be measured in units of measurement (McLeod, 2017). 
It is known that qualitative methods give an in-depth picture how and why things have happened. Their aim is to deeply understand the people and groups in their natural setting (McLeod, 2017). To strengthen the numerical findings received from the questionnaire and to check their objectivity, open questions were included. They enabled the respondents to answer in detail, and in their own words. Thus, the designed questionnaire consisted of 10 questions including close-ended, open-ended and the mixed ones (Appendix 1).

The questions of the first type provided the information on the characteristics of the respondents and numerical data to analyse them. The mixed questions were aimed at investigating the frequency of using swear words in everyday life, rating the reasons of using them and the emotions which they cause. Open questions implied receiving the respondents' opinion on what should be done to stop or at least to eliminate the swear word usage by young people.

All in all, 120 questionnaires were given to Ukrainian university students. The research analysis was made on 118 surveys (1 was not returned, 1 questionnaire was partially filled in and could not be considered valid).

\section{Results}

The following results were obtained.

Gender and Age. Out of all the respondents, there were 48 males and 70 females that constitute $41 \%$ and 59\% correspondingly. There were 2 age groups of the respondents: the juniors (18-19 years of old) and the seniors (22-23 years of old). Both groups were approximately equal in their number.

Respondents' Place of Origin. It was of particular interest to find out if the place of origin influences the Ukrainian students' speech culture. Thus, the question about their birthplace was offered in the questionnaire. The received data demonstrated that the majority of the students (53) come from Ukrainian towns. That makes up $45 \%$. The fewest number of the students are from villages -24 students. It makes only $20 \%$ of the respondents. $35 \%$ of the students (41) come from cities of Ukraine.

Frequency of Use. The question of how often the respondents use swear words implied 4 answers: constantly, rather often, from time to time, and never. 2 girls and 4 boys from the group of youngsters (18-19 years old) confessed that they constantly do it and it constitutes nearly $2 \%$ and $3 \%$ accordingly. The option "rather often" was chosen by 10 males and 10 females (around 8\%) and "from time to time" was selected by 2 boys and 32 girls that made up $2 \%$ and $27 \%$ of all respondents. It was interesting to find out that only $2 \%$ of young females never use these words in their everyday life.

As for the second group of respondents (22-23 years old), the following results were obtained. The first and the last options (constantly and never) were not chosen by the senior respondents. Yet, $19 \%$ of males and $7 \%$ of females rather often use the swear words in their everyday life. And, $8 \%$ of boys and $14 \%$ of girls apply to swearing from time to time.

Starting Point of Using Swear Words. To change the situation of using swear words by students it is necessary to find out when they started doing it. In view of this, the questionnaire contains the related question and the following options: since childhood, since high school and since becoming a university student. The results showed that not a single respondent chose the first option as the starting point of their usage. The majority of respondents began to use swear words when being at high school, particularly $76 \%$ of all the respondents. The rest (24\%) started at universities. It may seem strange that even those respondents who pointed out that they had never applied to these words answered this and the next questions. Hence, it can be implied that they were not sincere when declaring "I have never used swear words".

Motives of Using Swear Words. It is of paramount importance to know the reasons why modern students use swearing in their everyday speech. It will enable the pedagogues to work out the recommendations how to eliminate or at least to minimise this phenomenon. Besides, the question of motives will encourage them to reflect on it and to analyse their own behaviour which may become a tool of preventing them from swearing in the future. That is why this question was included into the questionnaire.

The respondents were to choose 5 items and to rate them from 1 to 3 starting from the most to the least important. Also, the students could add other motives that were not included in the list. The results are demonstrated separately for 2 groups in Table 1 . As it is seen from the obtained results, not all the options in the list were chosen.

In the junior group (62 respondents) the first place was given to the emotional relief (40\% of students), the chance to shock other people (19\%), and to be definitely clear when communicating with others (13\%). The second and the third important motives are considered the way to emotionally relieve themselves - 44\% and $34 \%$ accordingly. $16 \%$ of the youngsters thought the chance to be definitely clear less important and $13 \%$ are sure that swear words help persuade others more effectively. In the third place, this option was chosen by $19 \%$ of the students. And $13 \%$ of the respondents marked the chance to realise themselves as the driving force that makes them swear. 
Table 1. Rating of Motives of Using Swear Words by University Students

\begin{tabular}{|l|c|c|c|c|c|c|}
\hline & \multicolumn{3}{|c|}{ 62 Junior Students } & \multicolumn{3}{c|}{ 56 Senior Students } \\
(18-19)-23)
\end{tabular}

Source: systemised by the authors.

As for the senior group, the most important reason for them was the emotional relief which the usage of swear words brought: $55 \%$ in the first place; $50 \%$ in the second place and $46 \%$ in the third place. Unlike the junior group, the seniors pointed out the opportunity to show contempt with the help of swear words as the second important motive. On average, it constitutes $45 \%$. Less important, just as in the first case, was the fact that emotionally coloured swear words seemed to the respondents more persuasive.

Emotions Involved. Because all the respondents are of the opinion that swear words help get emotional relaxation, it seemed logical to find out what emotions are involved. The students were offered a list of various emotions to select: wonder, admiration, contempt, fear, satisfaction, unhappiness, pain, anger. The question also implied the respondents' own variant. The received information proved that there are similarities in using swear words by the juniors and the seniors in case of expressing negative emotions, particularly unhappiness, pain, anger. They are $18 \%$ and $20 \%$ for unhappiness, $21 \%$ of the juniors and $43 \%$ of the seniors swear because of pain, $31 \%$ of the junior respondents and $23 \%$ of the senior students do it in a fit of anger. The difference is seen in using swear words to express positive emotions. Unlike the juniors, the senior students almost do not use them being in high spirits. In addition, they offer their own variants of answers $-14 \%$ whereas only $3 \%$ of the junior students defined their emotions on their own.

What Should Be Done? One of the tasks of the research is what should be done to uplevel the speech culture of Ukrainian students and to eliminate their swearing. The respondents were offered the opportunity to share their ideas. Practically, the majority of them (76\%) answered that nothing could and should be done to change the situation. Among them, there were more junior students (85\%) and only $15 \%$ of the senior respondents responded negatively. The rest of the answers were grouped into 2 categories: various educational activities (14\%); social events (10\%).

Those who believe in the power of education are not sure that the use of swear words can be completely stopped. Yet, they argue that the following activities can be organised to eliminate their usage:

- to hold trainings on comparing the expressiveness of using swear and literary words;

- to offer students to compile mini-dictionaries of swear words with a list of synonyms that could express the same emotions but which can be used in social interaction;

- to organise the linguistic studies of swear word etymology;

- to develop students' speech culture competences at educational institutions;

- to include a separate module into the curriculum;

- to teach the social and business etiquette through gamification;

- to arrange meetings with public people and after-analysis activities;

- to organise a number of role games to enhance the speech culture of students.

The smallest group of the respondents (10\%) are sure that some social activities must be undertaken:

- to adopt the law on prohibiting the use of swear words in public; 
- to penalty those who break the speech culture etiquette;

- to make TV, radio and other mass-media control their speech culture more thoroughly.

\section{Discussion}

Insights on the self-expression with the swear words show that men are by far the most likely committers now and in the past (Guvendir 2015). It means that men swear more often and variously than females. It is traditionally believed that women do not use swear words in their speech or at least only a few of them do it (Mehl \& Pennebaker 2003).

The research results proved that university students irrespective of their gender swear. Now a growing tendency can be traced in Ukraine that young women are on equal terms with men in this respect. The situation is threatening because women will be raising their own children and, naturally, the question arises what speech culture they will be able to share with them. In addition to the above-mentioned belief, there is also a strong supposition in Ukraine that young people from the countryside are better-bred thanks to fixed family relations and religious ideas. As the research results show, the place of origin does not influence the respondents' speech culture. Students from villages and towns do not use swear words less than those from cities.

One general trend is typical to both investigated groups. Not a single student either from the first or the second group defined the reason of their using swear words as the break of public etiquette norms. It gives the ground to conclude that there is nothing to break. The level of speech culture is lowering and swearing is becoming increasingly naturalised in the Ukrainian community. The words and phrases which were strictly abandoned in public speeches, on TV, radio, printed media not long ago are widely being used now. The most powerful promoter of swear words is social networks. All in all, mass media and the Internet have levelled down the speech culture norms and loosened the rules of etiquette in Ukraine.

In mixed questions, the students were able to choose an option to express their own opinion. But the juniors did not take the chance. Possibly, they may have preferred not to bother themselves. On the contrary, the senior students were more thoughtful and thoroughly reflected their motives of using swear words in everyday speech. They gave their own options, among which pain, fear, fun, confidence and even selfdefence were mentioned. The same occurred with the question of emotions.

The typical young people's motives were to realise themselves and at the same time to be a part of the company. In their opinion, usage of swear words helped realise themselves and be a part of the company. They used them automatically without pondering, just to shock others. In this case, the senior students controlled their speech; only few of them mentioned that they applied to swearing without thinking about consequences. That is why, they did not intend to use them to shock others.

Psychologists state that swearing can occur with any emotion. It can elevate the intensity of negative emotions and at the same time, they can also enhance positive emotions (Eliason 2018). The obtained research results demonstrated that both senior and junior students swear to express their negative emotions more often than positive ones. The swear word usage in public is seen to be constantly growing. In scientists' opinion (Finn, 2017; Baruch, Prouska et al, 2017), there is a changing attitude towards the use of such words in the workplace and in social interactions. This shift leads to more acceptable attitude to swearing in public. That is why, the recommendations which were given by the respondents concerning the social activities have sense.

One of the Ukrainian social pedagogues, Shyrokoradiuk (2015) states that the most efficient activity is correction and prophylactic of using swear words. Particularly, she mentions the elucidatory conversations and thematic discussions, aimed at creating a negative image of swearing, various trainings and workshops, role games. It can allow students and their teachers adequately react against breaking the community speech culture.

Within this context, social psychologist Rostomova (2012) underlines that only development of communication skills can radically change the situation through expanding students' personal, spiritual, social and professional potential. She is sure that it is the lack of knowledge in speech culture and cultural forms of human interaction that aggravates the problem. Students can be interested in rhetoric lessons, conversation workshops, trainings in communicative abilities (to persuade, convince, dispute, keep on the dialogues, etc.). Moreover, one of the most significant tool to improve the speech culture is learning a foreign language.

The authors of the article are convinced that the problem must be settled in close cooperation of educational process subjects: students, university teachers, curators and administrative staff. Moreover, the complex of activities should be performed in every sphere of students' life: classes, extracurricular, public. Being practical pedagogues and curators of students' groups, the authors of this paper designed a complex of activities. It includes a set of various talks on the language and business etiquette in their future professions; common visits to the theatres and cinemas, museums and art galleries with their further discussion; questioning of their friends and summarising their own surveys; trainings in rhetoric skills; workshops in 
using literary language; visits to schools and conducting role games there. The talks with students on the etiquette rules in their future profession underline the importance of possessing literary language skills as the respondents are supposed to become teachers, managers, travel consultants. It means that these professions need people skills, i.e. skills and ability to effectively interact with others. The knowledge of business etiquette helps to build healthy relationships, nurture harmonious environment, show confidence and respect.

Common visits to the theatre performance or to the cinema show beauty, intelligence, attractiveness of the literary mother tongue, unite the group mates in extracurricular activities and inspire the students to keep to the speech culture. Further discussion of the seen performance or film gives a good practice to develop the necessary speaking and people skills. In these discussions in non-formal setting, the students also improve their rhetoric skills which are formed during trainings how to persuade, defend their own opinion, make independent conclusions, argue with opponents and at the same time respect other people's position.

A special accent is put on working out students' own questionnaires on using swear words. It is offered to use the Kahoo.it platform to make questions and to get answers to them immediately. The platform shows the answers, summarises them and shows a general picture of the place that swear words occupy in the students' lexicon. One more element to uplevel speech culture is to encourage the respondents to visit high schools. Obviously, future teachers do it during their school practice. Future tourism employees do it during vocation educational visits. They are asked to prepare the above-described questionnaires beforehand. On their visits and communication with high school students, they get the answers, analyse them and offer to discuss the problem with their respondents. Their own experience in the role of researchers minimises the use of swear words. During such visits students in cooperation with class mistresses organise and hold various games: simulations, interactives, situational, role and staging games, etc.

But the most effective activity, as the practice shows, is the commonly organised celebrations of such international and Ukrainian holidays as Day of Poetry (March, 21), Day of Knowledge (September, 1), Day of Book (April, 23), Day of Booklover (August, 9), Day of Ukrainian Writing (November, 9) and others.

Certainly, the results of introducing the designed complex of activities will be investigated in some period of time to check its effectiveness. Further, it is planned to examine and compare the ways of solving the problem in other countries.

\section{Conclusion}

The increasing trend of swear word usage by Ukrainian university students cannot be overseen. The penalty for using them in public does not eliminate the existing problem. The research results why Ukrainian university students swear show the opportunity to express oneself emotionally as the most typical motive for both males and females. Neither junior nor senior respondents consider the use of swear words to be the break of the public norms of etiquette. It implies the reduction of general culture and speech standards in the community. However, neither law on prohibiting swearing in public places nor penalty can radically change the situation. The educational activities must be more powerful in this respect.

\section{References:}

Aliaga, M. \& Gunderson, B. (2005). Interactive Statistics ( $3^{\text {rd }}$ ed). Dallas, TX, USA: Prentice Hall.

Bagdasarov, R. \& Tkachiov, A. (2012). Nevinnaia privychka ili smertnyi hrekh? Skvernoslovie - oruzhie massovoho porazheniia [Innocent habit or mortal sin? Swearing - a weapon of mass destruction]. Moscow: Danylovskiy Blahovestnik.

Baruch, Y., Prouska, R., Ollier-Malaterre, A. \& Bunk, J. (2017). Swearing at work: the mixed outcomes of profanity. Journal of Managerial Psychology, 32(2), 149-162. https://doi.org/10.1108/JMP-04-2016-0102

Byrne, E. (2017). Swearing is good for you: The amazing science of bad language. Profile Books.

Code of Ukraine on Administrative Offenses, Article 173 (2011). Retrieved October 11, 2018, from https://protocol.ua/ua/kodeks_ukraini_pro_administrativni_pravoporushennya_stattya_173_4/

Cohen, L., Manion, L. \& Morrison, K. (2000). Research methods in education (5th ed.). London: Routledge Falmer.

Eliason, N. (2018). How swearing leads to a shitty vocabulary. Life. Retrieved October 11, 2018, from https://www.nateliason.com/swearing/

Fägersten, K.B. (2012). Who is swearing now?: The social aspects of conversational swearing. Newcastle. Cambridge Scholar Publishing.

Finn, E. (2017). Swearing: The good, the bad \& the ugly. ORTESOL Journal, 34, 17-26. Retrieved October 13, 2018, from https://files.eric.ed.gov/fulltext/EJ1152392.pdf

Formanova, S. (2013). Invektyvy v ukrainskii movi [Invective in the Ukrainian language]. Thesis for Doctor of Philological Sciences, Odesa.

Grycak, Y. (2019). Narys istorii Ukrainy. Formuvannia modernoi natsii XIX-XX stolittia [Historical narratives of Ukraine. Formation of modern nation of the $19-20^{\text {th }}$ centuries]. Kyiv, Ukraine: Yakaboo Publishing.

Güvendir, E. (2015). Why are males inclined to use strong swear words more than females? An evolutionary explanation based on male intergroup aggressiveness. Language Sciences, 50, 133-139. http://dx.doi.org/10.1016/j.langsci.2015.02.003

Hansen, B. (2016). Swearing in the workplace: Announcing part 1 of Wrike's 2016 work management survey [blogpost]. Retrieved October 27, 2018, https://www.wrike.com/blog/swearing-workplace-announcing-part-1-wrikes-2016-work-management-survey/

Jay, K. \& Jay, T. (2015). Taboo word fluency and knowledge of slurs and general pejoratives: deconstructing the poverty-ofvocabulary myth. Language Sciences, 52, 251-259. https://doi.org/10.1016/j.langsci.2014.12.003 
Kleputs, L. (2009). Stratehii klasyfikatsii nenormatyvnoi leksyky [Strategies of non-standard lexis classification]. In the Proceedings of the I International Conference of Young Scientists (pp.84-87). Lviv, Ukraine: Publishing House of Lviv Polytechnic National University. Retrieved November 4, 2018, from http://ena.lp.edu.ua:8080/handle/ntb/6678

Lavryk, O. (2010). Non-standard lexicon in a modern Ukrainian youth press: morality-ethical aspect (on the material of "Sho"(What) magazine ). Visnyk Kharkivs'koho natsional'noho universytetu im. V.N. Karazina. Ser.: Sotsial'ni komunikatsiyi, 903(2), 49-53. Retrieved October 13, 2018 from http://dspace.univer.kharkov.ua/handle/123456789/3387

Ljung, M. (2011). Swearing: a cross-cultural linguistic study. Palgrave Macmillan, New York. https://doi.org/10.1057/9780230292376

McEnery, T. (2006). Swearing in English: bad language, purity power from 1586 to the present. London; New York: Routledge.

McLeod, S. (2017). Qualitative vs. Quantitative. Simply Psychology. Retrieved November 4, 2018, from https://www.simplypsychology.org/qualitative-quantitative.html

Mehl, M.R. \& Pennebaker, J.W. (2003). The sounds of social life: a psychometric analysis of students' daily social environments and natural conversations. Journal of Personality Social Psychology, 84, 857-870. https://doi.org/10.1037/0022-3514.84.4.857

Pinker, S. (2007). The Stuff of Thought: Language as a Window into Human Nature. New York, NY: Viking.

Rassin, R. \& Murris, P. (2005). Why do women swear? An exploration of reasons for and perceived efficacy of swearing in Dutch female students. Personal Individual Differences, 38, 1669-1674. https://doi.org/10.1016/j.paid.2004.09.022

Rostomova, L.M. (2012). Nenormatyvna leksyka: do pytannya pro kulturu spilkuvannya studentstva [Profanity: to the Question of Culture of Students' Communication]. Pedagogichnyi dyskurs, 12, 271-274. Retrieved October 13, 2018, from http://nbuv.gov.ua/UJRN/0peddysk_2012_12_64

Shevchenko, O. Y., \& Talko, O. (2017). Psyhologo-kulturolohichni aspekty vzhyvannya nenormatyvnoyi leksyky u molodizhnomu seredovyshchi. [Psychological and Cultural Aspects of the Use of Profanity in the Youth Environment]. Molodyi vchenyi, 3(43), 280-283. Retrieved November 17, 2018, from http://molodyvcheny.in.ua/files/journal/2017/3/65.pdf

Shyrokoradiuk, L.(2015). Psyhologichnyi aspect pidvyshchennia kultury movlennia shkoliariv [Phsycological aspect of uprising schoolchildren language culture]. Zbirnyk naukovykh prats': filosofiya, sotsiolohiya, psykholohiya, 20(2), 122-129. Retrieved November 17, 2018, from http://nbuv.gov.ua/UJRN/znpfsp_2015_20\%282\%29_20

Vingerhoets, J.J.M., Bylsma, L.M., \&de Vlam, C. (2013). Swearing: a biopsychological perspective. Psihologijske teme, 22 (2), $287-$ 304. Retrieved November 17, 2018, from https://psycnet.apa.org/record/2013-35574-008

Received: March 11, 2019

Accepted: November 28, 2019 


\section{The Questionnaire}

Appendix 1

This questionnaire is designed to identify the reasons why the students use swear words. It does not contain the questions aimed at collecting personal information. Will you give sincere answers to the following questions?

1. Your sex

male

2. Your age under 18 $18-19$

3. You come from: a village female

a town

yes, rather often never other

24 and over

a city

from time to time

5. If you use swearing, when did you begin to do it?

since early childhood

since school times

when I became a university student

6. What makes you apply to swearing? (Choose 3 most important drivers in the order of increasing their importance - 1- the most important, 2- important, 3 - less important):

it helps get along in the company

for persuading another person for showing contempt for emotional relief etiquette a tool of realising oneself for shocking others for being definitely clear automatically your variant

7. If you swear to express emotions, point out which ones:

\begin{tabular}{|c|c|c|}
\hline $\begin{array}{l}\text { wonder } \\
\text { admiration }\end{array}$ & $\begin{array}{l}\text { contempt } \\
\text { anger }\end{array}$ & $\begin{array}{l}\text { _- unhappiness } \\
\text { _- pain }\end{array}$ \\
\hline
\end{tabular}

8. What is your attitude to other people swearing in your presence:

positive indifferent

I am irritated I make a remark I act in the same way.

9. Why do you think swearing is so popular among university students? (Choose the most critical reason from the list) because it is used in my family because it is widely used in mass media

$$
\begin{aligned}
& \text { because it was often used in school } \\
& \text { environment and I got used to it } \\
& \text { because the level of speech etiquette is } \\
& \text { becoming lower in the society }
\end{aligned}
$$

your variant

10.What can help decrease the frequency of swearing by university students? Express your idea.

\section{Thank you for your answers!}

Identification of the drivers for swearing and acknowledgement of this fact are the first step to recovering. We hope that together we will achieve the success. 